\title{
New Flavonoids and other Constituents from Ouratea hexasperma (Ochnaceae)
}

\author{
Mário G. de Carvalho, ${ }^{*},{ }^{a}$ Luciano R. Suzart, ${ }^{a}$ Lorena C. Cavatti ${ }^{a}$ and \\ Maria Auxiliadora C. Kaplan ${ }^{b}$ \\ ${ }^{a}$ Departamento de Química, Universidade Federal Rural do Rio de Janeiro, Br 465 Km 7- Seropédica, \\ 23890-000 Rio de Janeiro-RJ, Brazil \\ ${ }^{b}$ Núcleo de Pesquisa em Produtos Naturais Bloco H, Av. Carlos Chagas Filho, 373, Cidade Universitária, \\ 21941-902 Ilha do Fundão, Rio de Janeiro-RJ, Brazil
}

\begin{abstract}
O estudo fitoquímico do extrato metanólico de galhos de Ouratea hexasperma (Ochnaceae) forneceu dois novos flavonóides, 7-O- $\beta$-D-glicopiranosil-6-(3-metilbut-2-enil)-5,4' diidroxiflavanonol (6- $\beta, \beta$-dimetilalil-7- $O-\beta$-D-glucopiranosil-aromadendrina) e $7-O-\beta-\mathrm{D}$ glicopiranosil-6-(3-metilbut-2-enil)-3,5,4'-triidroxiflavona (6- $\beta, \beta$-dimetilalil-7- $O$ - $\beta$-Dglucopiranosil-kaemperol) além de uma mistura de sitosterol e estigmasterol, lupeol, 3-O- $\beta$-Dglicopiranosil-sitosterol e o ácido 2,4-diidroxifenilacético. As estruturas dessas substâncias foram estabelecidas através de análise dos espectros de IV, EM-IES e RMN das substâncias naturais e dos derivados peracetílico e éter dimetílico da nova flavona, além de comparação com dados da literatura.
\end{abstract}

Chromatographical fractionation of the methanol extract from the branches of Ouratea hexasperma (Ochnaceae) afforded two new flavonoids, 7-O- $\beta$-D-glucopyranosyl-6-(3-methylbut2 -enyl)-5,4'-dihydroxyflavanonol (6- $\beta$, $\beta$-dimethylallylaromadendrin-7- $O$ - $\beta$-D-glucoside $)$ and 7-O- $\beta$-D-glucopyranosyl-6-(3-methylbut-2-enyl)-3,5,4'-trihydroxyflavone $(6-\beta, \beta$ dimethylallylkaempferol-7- $O-\beta$-D-glucoside) besides a mixture of sitosterol and stigmasterol, lupeol, sitosterol-3-O- $\beta$-D-glycopyranoside and 2,4-dihydroxyphenylacetic acid. The structures were established by analysis of IR, ESI-MS, and NMR spectra of the natural substances, and those of the dimethyl ether and peracetyl-derivatives of the new flavone, as well as comparison with literature values.

Keywords: Ochnaceae, Ouratea hexasperma, glucopyranosyl-prenylflavonoids, prenylflavanonol glucoside, prenylflavone glucoside, 2,4-dihydroxyphenylacetic acid

\section{Introduction}

Previous phytochemical and pharmacological investigations on Ouratea species (Ochnaceae) have shown the presence of terpenoids, isoflavonoids, flavonoid glycosides, and more frequently biflavones which are considered as chemical markers for this genus. ${ }^{1}$ DNA topoisomerase inhibition, cytotoxic and antitumoral activities of biflavonoids ${ }^{2-4}$ have been described as well as other pharmacological activities of extracts from Ouratea species. ${ }^{5-7}$ So far, the phytochemical study of $O$. hexasperma identified biisoflavanones hexaspermone $\mathrm{A}$, hexaspermone $\mathrm{B}$ and hexaspermone $\mathrm{C}$, biflavones (6

*e-mail: mgeraldo@ufrrj.br 6")-bigenkanine, 7,7"-dimethyl-lanaraflavone, 7"-methylagathisflavone and agathisflavone, as well as the mono flavonoids 5,7,4'-trimethoxy-isoflavone, epicatechin, 6- $C$-glycopyranosyl-luteolin and 3-O-glycopyranosylquercetin..$^{8-11}$ The present paper reports the results of an additional phytochemical study of the extract from the branches of $O$. hexasperma, describing the identification of two new prenylflavonoid glucosides, including some known compounds.

\section{Results and Discussion}

The chromatographic fractionation of the methanol extract from $O$. hexasperma branches afforded sitosterol and 
stigmasterol as an inseparable mixture, lupeol, sitosterol3-O- $\beta$-D-glucopyranoside, 2,4-dihydroxyphenylacetic acid (3) and two new flavonoids, 7-O- $\beta$-D-glucopyranosyl6- $\gamma, \gamma$-dimethylallyl-5,4'-dihydroxyflavanonol (1) and 7-O- $\beta$-D-glucopyranosyl-6- $\gamma, \gamma$-dimethylallyl-3,5,4' trihydroxyflavone (2) (Figure 1).

The known sterols, $\beta$-sitosterol glucoside, its acetyl derivative, and lupeol were identified by spectral data analysis and comparison with literature values. ${ }^{11,12}$

The flavanonol glucoside $\mathbf{1}$ was identified from its NMR and mass spectra. The aglycone moiety was deduced to be $\gamma, \gamma$-dimethylallylflavanonol by the presence of the fragment $m / z 355.1227\left(\mathrm{C}_{20} \mathrm{H}_{19} \mathrm{O}_{6}\right)$ in the HR-EISMS (Figure 2), which was supported by the ${ }^{1} \mathrm{H}$ NMR spectral data as follows: two doublets at $\delta 5.11$ and $4.55(J 11.0 \mathrm{~Hz})$ of $\mathrm{H}-2$ and $\mathrm{H}-3$; two doublets $(J 8.0 \mathrm{~Hz}, 2 \mathrm{H})$ of an AA'BB' system $\left(\mathrm{H}-2^{\prime}, 6^{\prime}\right.$ and $3^{\prime}, 5^{\prime}$, ring B), and two singlets at $\delta 6.22(\mathrm{H}-8)$ and 12.04 (HO-5) characteristic of a flavanonol structure. The presence of $\gamma, \gamma$-dimethylallyl group was identified by two signals of three-protons at $\delta 1.75$ and $1.61\left(-\mathrm{CMe}_{2}\right)$, multiplets at $\delta 3.31,3.14\left(\mathrm{C}_{2}-\mathrm{CH}=\mathrm{C}<\right)$, and the signal at $\delta 5.17$ (t, $7.0 \mathrm{~Hz}, \mathrm{CH}_{2}-\mathrm{CH}=\mathrm{C}<$ ). The ${ }^{13} \mathrm{C}$ NMR chemical shifts of the prenyl group (C-1'"'-5'”), the $\delta_{\mathrm{CH}}$ at $94.2(\mathrm{CH}-$ 8) and $\delta_{\mathrm{C}}$ at 199.7 (C-4) and 109.9 (C-6) detected in the ${ }^{13} \mathrm{C}$ NMR (BBD and DEPT) and HMQC spectra (Table 1) were compatible with this group being located at C-6 of flavononol (Figure 1). According to the values of $J_{\mathrm{H}-2, \mathrm{H}-3}$ $11 \mathrm{~Hz}, \delta_{\mathrm{CH}-2} 83.2$ and $\delta_{\mathrm{CH}-3} 71.8$, the aryl and hydroxyl substituents at C-2 and C-3 are equatorially oriented (2,3-trans), with the same stereochemistry proposed for xeractinol. ${ }^{13}$ The sugar moiety was identified from five additional resonances of oxymethyne carbons including a signal at $\delta_{\mathrm{CH}} 100.2\left(\mathrm{HC}-1\right.$ "), and of a $\mathrm{CH}_{2}$ at $60.7\left(\mathrm{H}_{2} \mathrm{C}\right.$ -
6") (Table 1), corresponding to a $O$ - $\beta$-D-glucopyranosyl moiety. ${ }^{14}$ The analysis of ${ }^{13} \mathrm{C}$ NMR (BBD and DEPT) and HMQC spectra, and data comparison of $\mathbf{1}$ (Table 1) with those of prenylflavanonol glycosides ${ }^{14,15}$ corroborated the structure of a 6-prenylflavanonol glycoside. The signals observed in the HMBC spectra such as ${ }^{\mathrm{n}} \mathrm{J}_{\mathrm{CH}}$ of C-7 and C-9 with H-8, C-6 with H-8, 1" ' and 2"', the chemical shift of CH-8 (94.2), and the nOe signal of H-1" [ $4.92(\mathrm{~d}, J 8.0 \mathrm{~Hz})]$ detected by irradiation at 6.22 (s, H-8) using the NOEDIFF technique, assigned the location of $\gamma, \gamma$-dimethylallyl and $O$-glucopyranosyl groups at the 6 and 7 positions, respectively (Figure 1). The peaks detected in the HR-ESI mass spectra (MS) at $\mathrm{m} / \mathrm{z}: 517.1747$ (M-H, 1a), 355.1227 (M-162, 1b), 327.1268 (1c), and 219.0696 [M - 162 $\left.\left(\mathrm{C}_{6} \mathrm{H}_{10} \mathrm{O}_{5}\right)-136\left(\mathrm{C}_{8} \mathrm{H}_{8} \mathrm{O}_{2}\right)\right]$ (Figure 2) and peaks detected by MS/MS (see experimental) confirmed the structure of the new flavonoid (1) as 7-O- $\beta$-D-glucopyranosyl-6- $\gamma, \gamma-$ dimethylallyl-5,4'-dihydroxyflavanonol (Table 1).

The structure of $\mathbf{2}$ was identified by NMR and mass spectra. The $\delta_{\mathrm{H}} 8.08(\mathrm{~d}, J 8.0 \mathrm{~Hz}), 6.95(\mathrm{~d}, J 8.0 \mathrm{~Hz})$ of an AA'BB' system (H-2',6' and 3', 5', ring B), two singlets at $\delta_{\mathrm{H}} 12.04$ (HO-5) and $6.89(\mathrm{H}-8)$ in the ${ }^{1} \mathrm{H}$ NMR spectrum, and the chemical shifts of C-4 (176.1) and $\mathrm{CH}-8$ (93.2) detected in the ${ }^{13} \mathrm{C}$ NMR were in agreement with a kaempferol structure with a substituent at position 6 . Further examination of the ${ }^{1} \mathrm{H},{ }^{13} \mathrm{C}$ NMR (BBD and DEPT) and HMQC spectra, and comparison with the spectral data of $\mathbf{1}$ and of $8-\gamma, \gamma$-dimethylallylkaemperol glucosides ${ }^{14}$ allowed the identification of the $\gamma, \gamma$-dimethylallyl (C-1"'-5'") side chain and the $O-\beta-\mathrm{D}$-glucopyranosyl (C-1"-6") moiety (Table 1). The structure of the prenylkaempferol glycoside was supported by peaks detected in the HR-ESI mass spectra of 2 with $\mathrm{m} / \mathrm{z} 515.1550$ (M-H, 2c), 353.1049 (M-

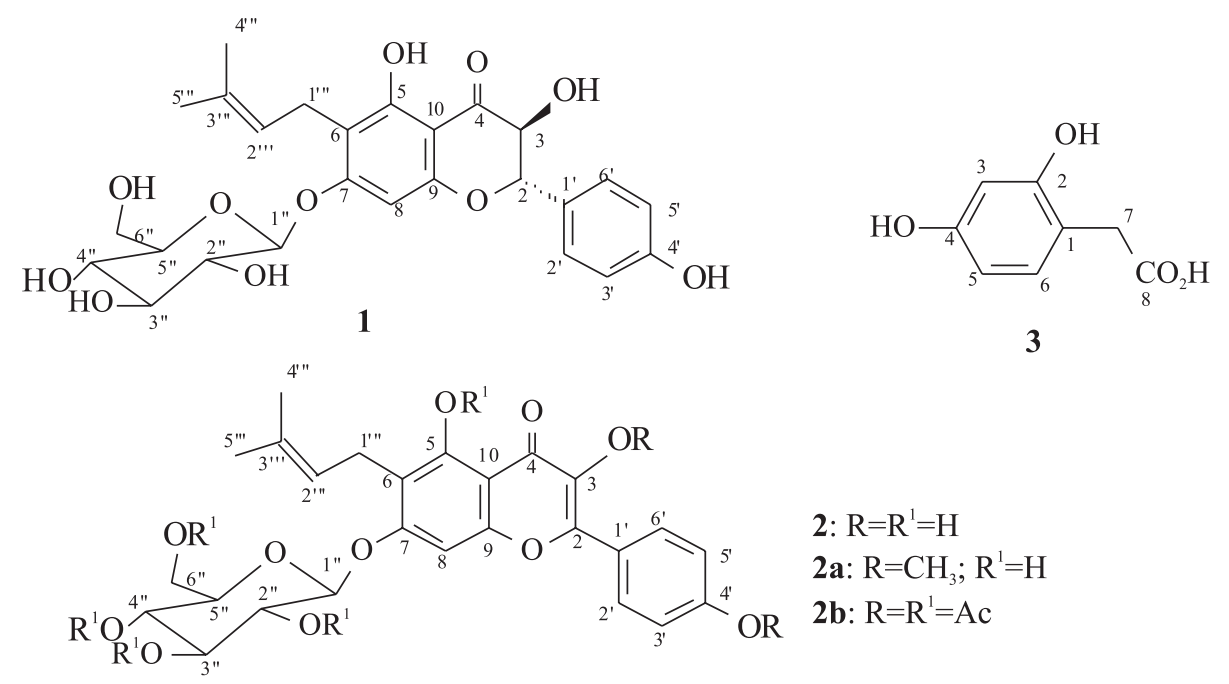

Figure 1. Structures of the new flavonoids and 2,4-dihydroxyphenylacetic acid isolated from $O$. hexasperma and the derivates $\mathbf{2 a}$ and $\mathbf{2 b}$. 
$162,2 d)$ and $219.0696\left[\mathrm{M}-162\left(\mathrm{C}_{6} \mathrm{H}_{10} \mathrm{O}_{5}\right)-134\left(\mathrm{C}_{8} \mathrm{H}_{6} \mathrm{O}_{2}\right)\right]$ (Figure 2), besides peaks detected by MS/MS spectra (see Experimental). The signals of nOe at $\delta_{\mathrm{H}} 6.89(\mathrm{H}-8)$ and $\delta_{\mathrm{H}}$
4.90 (H-1"), detected by irradiation at 4.90 (H-1"), and at 6.89 (H-8), respectively, assigned location of the allyl group at $\mathrm{C}-6$, and the $O$-glucopyranosyl unit at $\mathrm{C}-7$ in the flavone<smiles>[R]Oc1cc2oc(-c3ccc(O)cc3)c(O)c(=O)c2c(O)c1CC=C(C)C</smiles>

Figure 2. Proposed fragments for the principal peack detected in ESI-MS of $\mathbf{1}$ and $\mathbf{2}$.

Table 1. ${ }^{1} \mathrm{H}(200 \mathrm{MHz})$ and ${ }^{13} \mathrm{C}(50.3 \mathrm{MHz})$ NMR data of $\mathbf{1}, \mathbf{2}$, and $\mathbf{2} \mathbf{b}^{\mathrm{a}, \mathrm{b}}$

\begin{tabular}{|c|c|c|c|c|c|c|c|}
\hline \multirow{2}{*}{$\mathrm{C}$} & \multicolumn{3}{|c|}{$\boldsymbol{1}\left({ }^{1} \mathrm{Hx}{ }^{13} \mathrm{C}-\mathrm{COSY},{ }^{\mathrm{n}} J_{\mathrm{CH}}\right)$} & \multicolumn{2}{|c|}{$2\left({ }^{1} \mathrm{Hx}{ }^{13} \mathrm{C}-\mathrm{COSY},{ }^{1} J_{\mathrm{CH}}\right)$} & \multicolumn{2}{|r|}{$2 \mathbf{b}$} \\
\hline & $\delta \mathrm{c}$ & $\delta_{\mathrm{H}}($ mult, $J$ in $\mathrm{Hz})$ & ${ }^{2,3} J_{\mathrm{CH}}$ & $\delta \mathrm{c}$ & $\delta_{\mathrm{H}}($ mult,$J$ in $\mathrm{Hz})$ & $\delta \mathrm{c}$ & $\delta_{\mathrm{H}}($ mult,$J$ in $\mathrm{Hz})$ \\
\hline 2 & 83.2 & $5.11(\mathrm{~d}, 11.0)$ & & 156.4 & & 158.8 & - \\
\hline 3 & 71.8 & $4.55(\mathrm{~d}, 11.0)$ & & 136.0 & & 133.7 & - \\
\hline 4 & 199.7 & - & $\mathrm{H}-2$ & 176.1 & - & 170.1 & - \\
\hline 5 & 159.6 & - & & $160.6^{c}$ & - & 152.7 & - \\
\hline $\mathrm{OH}$ & - & $12.04(\mathrm{~s})$ & & - & $12.04(\mathrm{~s})$ & - & - \\
\hline 6 & 109.9 & - & $\mathrm{H}-1$ "' and $\mathrm{H}-2$ "', $\mathrm{H}-8$ & 111.8 & - & 120.5 & - \\
\hline 7 & 163.2 & - & $\mathrm{H}-8$ & $159.6^{\mathrm{c}}$ & - & 155.8 & - \\
\hline 8 & 94.2 & $6.22(\mathrm{~s})$ & & 93.2 & $6.89(\mathrm{~s})$ & 98.4 & $7.01(\mathrm{~s})$ \\
\hline 9 & 160.6 & - & H-8 & 154.6 & - & 154.3 & - \\
\hline 10 & 101.8 & - & & 104.4 & - & 112.5 & - \\
\hline 1 ' & 127.6 & - & $\mathrm{H}-3^{\prime}, 5^{\prime}$ & 121.6 & - & 127.2 & - \\
\hline $2^{\prime}, 6^{\prime}$ & 129.7 & $7.30(\mathrm{~d}, 8.0)$ & $\mathrm{H}-2$ & 129.9 & $8.08(\mathrm{~d}, 8.8)$ & 129.5 & $7.82(\mathrm{~d}, 8.0)$ \\
\hline $3^{\prime}, 5^{\prime}$ & 115.1 & $6.79(\mathrm{~d}, 8.0)$ & & 115.5 & $6.95(\mathrm{~d}, 8.8)$ & 122.0 & $7.26(\mathrm{~d}, 8.0)$ \\
\hline $4^{\prime}$ & 158.0 & - & $\mathrm{H}-3^{\prime}, 5^{\prime}, \mathrm{H}-2^{\prime}, 6^{\prime}$ & 159.6 & - & 148.7 & - \\
\hline $1 "$ & 100.2 & $4.92(\mathrm{~d}, 8.0)$ & & 100.4 & $4.90(\mathrm{~d}, 8,0)$ & 100.8 & $5.23(\mathrm{sbr})$ \\
\hline $2 "$ & 73.4 & $3.29(\mathrm{~m})$ & $\mathrm{H}-4, ", 5, "$ & 73.4 & $3.29(\mathrm{~m})$ & 70.9 & $5.0(\mathrm{~m})$ \\
\hline $3 "$ & 76.7 & $3.29(\mathrm{~m})$ & H-5"' H-4"” & 76.8 & $3.33(\mathrm{~m})$ & 72.5 & $5.0(\mathrm{~m})$ \\
\hline $4 "$ & 69.6 & $3.18(\mathrm{~m})$ & $\mathrm{H}-5^{\prime}, ", \mathrm{H}-2$ & 69.7 & $3.36(\mathrm{~m})$ & 68.0 & $5.0(\mathrm{~m})$ \\
\hline $5 "$ & 77.2 & $3.35(\mathrm{~m})$ & $\mathrm{H}-4$ "', $\mathrm{H}-2$ & 77.2 & $3.44(\mathrm{~m})$ & 72.5 & $4.0(\mathrm{~m})$ \\
\hline $6 "$ & 60.7 & $3.50(\mathrm{~m})$ & & 60.7 & $3.51(\mathrm{~m})$ & 62.0 & $4,23(\mathrm{sbr})$ \\
\hline $1 "$, & 21.0 & $3.31 / 3,14(\mathrm{~m})$ & & 21.3 & 3.31 and $3.27(\mathrm{~m})$ & 29.7 & $3.29(\mathrm{~d}, 8.0)$ \\
\hline $2 "$, & 122.5 & $5.17(\mathrm{t}, 7.0)$ & & 122.2 & $5.08(\mathrm{~m})$ & 123.1 & $5.36(\mathrm{~m})$ \\
\hline $3 "$, & 130.7 & - & & 130.7 & - & 128.8 & - \\
\hline $4 "$, & 25.7 & $1.61(\mathrm{~s})$ & & 25.6 & $1.64(\mathrm{~s})$ & 25.6 & $1.64(\mathrm{~s})$ \\
\hline $5 "$, & 17.7 & $1.75(\mathrm{~s})$ & & 17.8 & $1.77(\mathrm{~s})$ & 17.9 & $1.77(\mathrm{~s})$ \\
\hline$\left(\mathrm{OCOCH}_{3}\right)_{7}^{\mathrm{b}}$ & - & - & - & - & $\left({ }^{b}\right)$ & & \\
\hline
\end{tabular}


nucleous (Figure 1, Table 1). The analyses of ${ }^{1} \mathrm{H}$ and ${ }^{13} \mathrm{C}$ NMR spectra of the methoxyl derivative $\mathbf{2 a}$, and the acetyl derivative 2b (see Experimental and Table 1) were used as additional information to confirm the structure of $\mathbf{2}$. nOe signals detected in the NOEDIFF spectrum of $\mathbf{2 a}$, at $\delta_{\mathrm{H}} 5.1$ (H-1'), $8.05\left(\mathrm{H}-2^{\prime}, 6\right.$ '), and $7.18(\mathrm{H}-3$ ',5' $\delta)$ by irradiation at $\delta_{\mathrm{H}} 6.90(\mathrm{H}-8), 3.85(\mathrm{MeO}-3)$ and at $3.87\left(\mathrm{MeO}-4^{\prime}\right)$, respectively, confirmed the location of two $O$-methyl groups at 3 and 4', and the $O$-glucopyranosyl group at position 7 (see Experimental). Comparison of the above data with those of $8-\gamma, \gamma$-dimethylallylkaemperol glycosides ${ }^{15}$ established the structure of $\mathbf{2}$ as the new flavonol glycoside, $6-\gamma, \gamma-$ dimethylallylkaempferol-7-O- $\beta$-D-glucopyranoside.

Related compounds have been previously isolated from other plant species, such as 7-O-glycopyranosyl-6-prenyl$3,5,3$ ', 4'-tetrahydroxyflavanone, the only glycoside of this type isolated from Ochnaceae (Ochna integerrima), ${ }^{15}$ 7-O-glycopyranosyl-6-(3-hydroxy-3-methyl-butyl-3,5,4'trihydroxyflavanone isolated from Phellodendron chinese (Rutaceae), ${ }^{16}$ and the diphyllosides identified in Epimedium diphyllum (Berberidaceae). ${ }^{14}$

The structure of the dihydroxy-phenylacetic acid $\mathbf{3}$ was based on the IR $\left.v_{\max } / \mathrm{cm}^{-1}: 3437-2160(\mathrm{O}-\mathrm{H}), 1695(\mathrm{C}=\mathrm{O})\right]$, and NMR spectra. Its ${ }^{1} \mathrm{H}$ NMR (1D and 2D) in MeO- $d_{4}$ displayed three signals of an aromatic $\mathrm{ABC}$ system, and a singlet at $\delta 3.4(2 \mathrm{H})$, whereas the ${ }^{13} \mathrm{CNMR}$ (BBD and DEPT) in $\mathrm{MeO}-d_{4}$ showed signals at $\delta 130.2(\mathrm{CH}), 104.9(\mathrm{CH})$, 104.1 $(\mathrm{CH})$, and $43.7\left(\mathrm{CH}_{2}\right)$, besides five quaternary carbon including the carboxylic acid signal $\left(\delta_{\mathrm{C}} 176.9\right)$. These data were compatible with the molecular formula $\mathrm{C}_{8} \mathrm{H}_{8} \mathrm{O}_{4}$, further supported by mass spectra $\left(\mathrm{m} / \mathrm{z} 168, \mathrm{M}^{+}\right)$. Comparison of the NMR data of $\mathbf{3}$ with those of 2,5-dihydroxyphenyl- and 3,4-dihydroxyphenyl-acetic acids recorded in $\mathrm{CDCl}_{3}+$ DMSO- $d_{6},{ }^{17}$ 2,4-dihydroxyphenyl acetic acid recorded in $\mathrm{D}_{2} \mathrm{O},{ }^{18}$ as well as using spectral prediction software, led us to propose the structure of $\mathbf{3}$ as 2,4-dihydroxyphenyl acetic acid, what hydrogen and ${ }^{13} \mathrm{C}$ chemical shift are found in the literature but in different solvent $\left(\mathrm{D}_{2} \mathrm{O}\right) .{ }^{18}$ This compound has been previously isolated from Nigella damascena seeds (Pamiculaceae) ${ }^{19}$ and Nigella damascena seeds. ${ }^{20}$

\section{Experimental}

\section{General procedures}

Melting points have not been corrected. IR spectra were recorded on a Perkin-Elmer 1605 FT-IT spectrophotometer. ${ }^{1} \mathrm{H}(200.0 \mathrm{MHz})$ and ${ }^{13} \mathrm{C}(50.3 \mathrm{MHz}) \mathrm{NMR}$ spectra were recorded on a Brüker AC 200 spectrometer using DMSO- $d_{6}$, $\mathrm{CD}_{3} \mathrm{OD}$ or $\mathrm{CDCl}_{3}$ with TMS as internal standard. HRESI mass spectra were obtained with a Brüker Daltonics
UltrOTOF-Q, Billerica, MA, spectrometer using $\left(\mathrm{H}_{2} \mathrm{O}\right.$, Ar as $\mathrm{CAD}$ ), $\mathrm{CE} 20 \mathrm{eV}$ for $\mathrm{MS}$ and $45 \mathrm{eV}$ for MS/MS in negative mode. Electron Ionization Mass Spectra (LREI-MS) of $\mathbf{3}$ was taken using a gas chromatograph coupled to a mass spectrometer (GC-MS) on a Varian Saturn 2000 using an ion trap at $70 \mathrm{eV}$. The Advanced Chemistry Development (ACD/ Labs) software V8. 14 for Solaris 1994-2007 ACD/Labs was used for prediction of ${ }^{1} \mathrm{H}$ and ${ }^{13} \mathrm{C}$ NMR chemical shifts of 3 . Column chromatography with silica gel (Vetec and Aldrich 0.05-0.20 mm) and Sephadex LH-20 (Sigma, USA); silica gel F254 G (Vetec) was used for preparative TLC; aluminum backed (Sorbent) silica gel plates w/UV254 were used for analytical TLC, with visualization under UV (254 and 366 nm), with $\mathrm{AlCl}_{3}: \mathrm{EtOH}$ (1\%), Lieberman-Burchard and/or Godin reagents, or exposure to iodine vapor.

\section{Plant material}

The branches of Ouratea hexasperma St.-Hil. (Ochnaceae) were collected in João Pessoa, Paraíba State, Brazil, in October 2002. Voucher specimen (No. JPB-21438) is deposited at the Herbarium Prof. Lauro Pires Xavier Universidade Federal da Paraíba, João Pessoa-PB, Brazil.

\section{Extraction and isolation}

The dried and powdered branches of $O$. hexasperma $(410.0 \mathrm{~g})$ were extracted with methanol at room temperature. The solvent was removed under vacuum furnishing a residue (44.0 g). The crude methanol residue ( $30.0 \mathrm{~g}$ ) was filtered on silica gel with $\mathrm{CH}_{2} \mathrm{Cl}_{2}$ and EtOAc, yielding, after removal of the organic solvent, two residues named OHMC (196.0 mg) and OHMAc (15.5 g). The residue OHMC was fractionated by $\mathrm{CC}$ on silica gel eluted with a mixture of $\mathrm{CH}_{2} \mathrm{Cl}_{2}$ :EtOAc with increasing polarity to EtOAc (100\%), and the resulting fractions grouped according to their TLC profile. Fractions 2-10 yielded a hydrocarbon mixture, $\mathrm{Fr}_{15-25}$ furnished a mixture of steroids, and $\mathrm{Fr}_{27-40}$ yielded lupeol $(300 \mathrm{mg})$. Fraction OHMAc $(10.0 \mathrm{~g})$ was fractionated on a silica gel column, eluted with $\mathrm{CH}_{2} \mathrm{Cl}_{2}: \mathrm{MeOH}$ with increasing polarity to $100 \% \mathrm{MeOH}$. Thirthy sub fractions were collected, and assembled according to their composition, as checked by TLC. The sub fractions 2-4 yielded a mixture of sitosterol and stigmasterol $(25.0 \mathrm{mg})$; fractions 6-7 furnished a residue ( $\mathrm{mp} 308-310^{\circ} \mathrm{C}, 40.0 \mathrm{mg}$ ) insoluble in chloroform, that was identified as sitosterol glycoside, from the formation of its acetyl derivative $\left(\mathrm{Ac}_{2} \mathrm{O}\right.$ :Pyridine). Fractions 8-9 were purified by preparative TLC using $\mathrm{CH}_{2} \mathrm{Cl}_{2}: \mathrm{MeOH}$ (8:2) to yield compound $\mathbf{3}$ (gum, $5.0 \mathrm{mg}$ ). $\mathrm{Fr}_{11-15}$ was submitted to Sephadex LH-20 column employing methanol as eluent. First pure fractions were 
grouped and crystallized from ethyl acetate to give $\mathbf{1}(\mathrm{mp}$ $172-173{ }^{\circ} \mathrm{C}, 90.0 \mathrm{mg}$ ), whereas the last fractions yielded a mixture of $\mathbf{1}$ and $\mathbf{2}$. $\mathrm{Fr}_{20-25}$ was submitted to Sephadex LH-20 CC using methanol as eluent, to furnish a mixture of $\mathbf{1}$ and $\mathbf{2}$. Last chromatographic fractions yielded $\mathbf{2}$ as an yellow solid (mp $179-180{ }^{\circ} \mathrm{C}, 80.0 \mathrm{mg}$ ). The flavone 2 was treated with diazomethane to yield $\mathbf{2 a}$ (gum, $12 \mathrm{mg}$ ), and with $\mathrm{Ac}_{2} \mathrm{O}$ /pyridine (1:1) to form the peracetyl derivative 2b (gum, 20 mg; Table 1).

7-O- 3 -D-glucopyranosyl-6-(3-methylbut-2-enyl)-5,4'dihydroxyflavanonol (1)

mp $172-173^{\circ} \mathrm{C}$ (EtOAc). ${ }^{1} \mathrm{H}$ NMR $(200 \mathrm{MHz})$ and ${ }^{13} \mathrm{C}$ (50.3 MHz) DMSO-d $\mathrm{d}_{6}$, Table 1; ESI-MS $\left[\mathrm{H}_{2} \mathrm{O}\right] \mathrm{m} / z$ (ion, \%): $607.2093\left(\mathrm{M}-\mathrm{H}+5 \times \mathrm{H}_{2} \mathrm{O}, 10\right), 553.1509(\mathrm{M}-\mathrm{H}+$ $\left.2 \times \mathrm{H}_{2} \mathrm{O}, 75\right), 517.1747$ (1a, M - H, 100), 515.1508 $\left(\mathrm{M}-\mathrm{H}-\mathrm{H}_{2}, 90\right), 355.1227$ (1b, 55), 327.1268 (1c, 9) $255.2360\left(219+\mathrm{H}_{2} \mathrm{O}, 10\right)$; MS/MS: $\{553\}: 515.1628(45)$, 355.1240 (100); $\{517\}$ : 517.1739 (30), 515.1623 (45), 355.1235 (100), 327.1268 (15), 219.0696 (20); $\{515\}$ : 355.1235 (100), 327.1268 (20), Figure 1.

7-O-ß-D-glucopyranosyl-6-(3-methylbut-2-enyl)-3,5,4'trihydroxyflavone (2)

mp 179-180 ${ }^{\circ} \mathrm{C}$ (amorphous powder); ${ }^{1} \mathrm{H}$ NMR (200 MHz) and ${ }^{13} \mathrm{C}$ NMR (50.3 MHz) DMSO- $d_{6}$ Table 1; ESI-HRMS [ $\left.\mathrm{H}_{2} \mathrm{O}\right] \mathrm{m} / z$ (ion, \%): $605.1894\left(\mathrm{M}-\mathrm{H}+5 \times \mathrm{H}_{2} \mathrm{O}\right.$, 10), $551.1331\left(\mathrm{M}-\mathrm{H}+2 \times \mathrm{H}_{2} \mathrm{O}, 10\right), 515.1550(2 \mathrm{c}, \mathrm{M}-\mathrm{H}$, 100;), $399.1319\left(219+[162]+\mathrm{H}_{2} \mathrm{O}, 15\right), 353.1049$ (2d, 2), $255.2344\left(219+\mathrm{H}_{2} \mathrm{O}, 10\right)$; MS/MS: $\{515\}: 353.1073$ (100); \{353\}: (219.0594, 100), Figure 1.

7-O- $\beta$-D-glucopyranosyl-6-(3-methylbut-2-enyl)-3,4'dimethoxy-5-hydroxyflavo-ne (2a)

A methanol solution of $2(12 \mathrm{mg})$ was treated with ethereal diazomethane, to yield the dimethyl ether $2 \mathbf{a}$ (12 $\mathrm{mg}$, gum): ${ }^{1} \mathrm{H}$ NMR (200 MHz, DMSO- $\left.d_{6}\right) \delta 13.0$ (s, HO), 8.05 (d, J $\left.8.0 \mathrm{~Hz}, \mathrm{H}-2^{\prime}, 6^{\prime}\right), 7.18$ (d, J 8.0 Hz, H-3',5'), 6.9 (s, H-8), 5.1 (d, J 9 Hz, H-1"), 5.2 (m, H-2"'), 4.1 (brs, H-6"), 3.1-3.7 (m, H-2",3",4",5" and H-1"'), 3.85 (s, MeO-3), 3.87 (s, MeO-4'), 1.8 (s, H-5'”, 3H), 1.6 (s, H-4 "', $3 \mathrm{H}) ;{ }^{1} \mathrm{H}\left\{{ }^{1} \mathrm{H}\right\}$-nOe by NOEDIFF experiments: $\mathrm{H}-8$ $(\delta 6.9)\{\mathrm{H}-1$ '” (5.1)\}, MeO-3 (3.85) \{H-2', 6'(8.05)\}, MeO-4' (3.87) $\left\{\mathrm{H}-3^{\prime}, 5^{\prime}(7.18)\right\}$.

\section{Peracetyl derivative of $\mathbf{2}(\mathbf{2 b})$}

A mass of $25 \mathrm{mg}$ of $\mathbf{2}$ was dissolved in a mixture of $\mathrm{Ac}_{2} \mathrm{O}$ :pyridine (1:1) and the solution was allowed to stand for $24 \mathrm{~h}$ at room temperature. The usual work-up yielded 2b (20 mg, gum): ${ }^{1} \mathrm{H}\left(200 \mathrm{MHz}, \mathrm{CDCl}_{3}\right)$ and ${ }^{13} \mathrm{C} \mathrm{NMR}$ (50.3 $\mathrm{MHz}, \mathrm{CDCl}_{3}$ ), Table 1 .

\section{2,4-dihydroxyphenylacetic acid (3)}

Gum; IR (KBr) $\left.v_{\max } / \mathrm{cm}^{-1}\right): 3437-2160(\mathrm{OH}), 2922,1695$ $(\mathrm{C}=\mathrm{O}), 1604,1558,1452$ and $1293 ;{ }^{1} \mathrm{H}$ NMR $(200 \mathrm{MHz}$, MeO- $\left.d_{4}\right) \delta 6.85$ (d, J 8.0 Hz, H-6), 6.28 (d, J $2.4 \mathrm{~Hz}, \mathrm{H}-3$ ), 6.20 (dd, J 8.0, $2.4 \mathrm{~Hz}, \mathrm{H}-5)$ and 3.4 (s, 2H, H-7); ${ }^{13} \mathrm{C}$ NMR (50.3 MHz, DMSO- $d_{6}$ ) $\delta 176.9$ (C-8), 158.9 (C-4), 156.7 (C-2), 130.2 (CH-6), 115.4 (C-1), 104.1 (CH-3), 104.9 (CH-5), $43.7\left(\mathrm{CH}_{2}-7\right)$. LRMS: $\mathrm{m} / z(\%)$ : $168\left(\mathrm{M}^{+}, 2 \%\right)$, and $150\left(\mathrm{M}^{+}-\mathrm{H}_{2} \mathrm{O}, 100 \%\right)$.

\section{Acknowledgments}

The authors are grateful to CNPq, FAPERJ and CAPES for scholarships and financial support, as well as to T.M.S. da Silva and M. de F. Agra for providing the plant material and N. P. Lopes of Faculdade de Farmácia-USP-Ribeirão Preto for the HR-ESIMS.

\section{Supplementary Information}

Supplementary data are available free of charge at http:// jbcs.sbq.org.br, as PDF file.

\section{References}

1. Suzart, L. R.; Daniel, J. F. de S.; Carvalho, M. G. de; Kaplan, M. A. C.; Quim. Nova 2007, 30, 984.

2. Carvalho, M. G. de; Velandia, J. R.; de Oliveira, J. C. C.; Echevarria, A.; Braz-Filho, R.; Grynberg, N. F. In Phytochemical and Pharmacologiy II of the Series "Recent Progress in Medicinal Plants", Majumdar, D.K.; Govil, J. N.; Singh, V. K. eds., SCI Tech Publishing LLC: Texas, 2002, vol. 8, p. 77.

3. Grynberg, N. F.; Carvalho, M. G. de; Velandia, J. R.; Oliveira, M. C.; Moreira, I. C.; Braz-Filho, R.; Echevarria, A.; Braz. J. Med. Biol. Res. 2002, 35, 819.

4. Daniel, J. F. de S.; Alves, C. C. F.; Grivicich, I.; Rocha, A. B. da; Carvalho, M. G. de; Indian J. Pharmacol. 2007, 39, 184.

5. Cortes, S. F.; Veladares, J. Y.; Oliveira, A. B. de; Lemos, S.V.; Barbosa, M. P. T.; Braga, F. C.; Planta Med. 2002, 68, 412.

6. Gonçalves, E.; Felicio, J. D.; Pinto, M. M.; Braz. J. Med. Biol. Res. 2001, 34, 1453.

7. Sampaio, M. P.; Oliveira, M. M. de; An. Acad. Bras. Cienc. $\mathbf{1 9 7 5}, 47,149$.

8. Moreira, I. C.; Sobrinho, D. C.; Carvalho, M. G. de; Braz-Filho, R.; Phytochemistry 1994, 35, 1567.

9. Daniel, J. F. D. S.; de Carvalho, M. G.; Cardoso, R. D. S.; Agra, M. de F.; Eberlin, M. N.; J. Braz. Chem. Soc. 2005, 16, 634.

10. Moreira, I. C.; Carvalho, M. G. de; Bastos, A. B. F. O.; BrazFilho, R.; Phytochemistry 1999, 51, 833.

11. Velandia, J.R.; Carvalho, M. G. de; Braz-filho, R.; Werle A. A.; Phytochem. Anal. 2002, 13, 283. 
12. Velandia, J. R.; PhD Thesis, Universidade Federal Rural do Rio de Janeiro, Brazil, 1997.

13. Dokkedal, A. L.; Lavarda, F.; Sandos, L.C. dos; Vilegas, W.; J. Braz. Chem. Soc. 2007, 18, 437.

14. Mizuno, M. N.; Iinuma, M.; Tanaka, T.; Sakakibara, N.; Fujikawa, T.; Hanioka, S.; Ishida, Y.; Liu, X.; Murata, H.; Phytochemistry 1988, 27, 3645.

15. Likhitwitayawuid, K.; Rungserichai, R.; Ruangrungsi, N.; Phadungcharoen, T.; Phytochemistry 2001, 56, 353.
16. Survey, D. B.; Ragai, K. I.; Phytochemistry 1996, 43, 921.

17. Sigma-Aldrich Co. Catalog, Copyright 1998, 2, 1117A and 1037C.

18. Chiba, T.; Akizawa, T.; Matsukawa, M.; Dawai, N.; Kono, Y.; Yoshioka, M.; Chem. Pharm. Bull. 1997, 45, 93.

19. Agradi, E.; Fico, G.; Cillo, F.; Franci, F.; Planta Med. 2001, $67,553$.

20. Fico, G.; Braca, A.; Tome, F.; Morelli, I.; Pharm. Biol. 2000, $38,371$. 